Computerized Axiographic System を利用した 顎関節機能不全を伴う症例の下顎位の診断とその治療

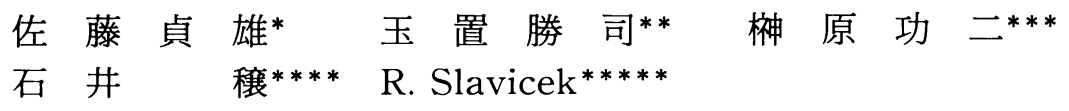

\title{
Diagnosis and Treatment of the Mandibular Position of a Case Associated with Temporomandibular Joint Dysfunction that Employed the Computerized Axiographic System
}

\author{
Sadao Sato* Katsuji Tamaki** Koji Sakakibara*** Yutaka Ishii**** \\ and R. Slavicek***
}

The craniomandibular system (CMS) is composed of the bones of the temporomandibular joint, cartilage, the articular disk, connective tissue behind the articular disk, and ligaments, in addition to the muscles associated with the masticatory system. The CMS functions in cooperation with the neuromuscular system and occlusion, carries out the functions of mastication, swallow, phonation and respiration, which are the principal functions of the masticatory organ.

While performing these activities it also carries out the task of preventing excessive retrusive and lateral deviations of the mandible, and positions the mandible in the correct anterior position. For example, because of the blood supply from an abundant vascular network, the connective tissue behind the joint, together with the lateral and collateral ligaments, prevent retrusive deviations of the mandibular condyle. The important function of positioning the mandible to the anterior is performed by the closing muscles, which include the superior head of lateral pterygoid muscle in conjunction with the mandibular condyle and articular disk, a portion of the anterior region of the temporalis muscle, and a portion of the deep head of the masseter muscle.

The mandibular condyle is prevented from excessive retrusion by guidance of the mandible to the anterior owing to interdigitation of the maxillary and mandibular teeth, as well as to their occlusal guidance. It appears that this functions to protect the organs of hearing and equilibrium, which are behind the temporomandibular joint. In addition, the harmonious relationship of the CMS and occlusion are thus able to function together to maintain balance by placing the mandible in a forward position.

* 神奈川歯科大学矯正学教室

** 神奈川歯科大学補経学第 3 講座

***サカキバラデンタルラボ東京

**** ガンマーラボ横浜

*****ウィーン大学補綴学教室オーストリア 
It has been suggested that most of the functional disturbances in the temporomandibular joint result from imbalances in the CMS and occlusion. The basic issues are the function of occlusal guidance , whereby the mandibular condyle is positioned forward by the CMS, and the forced retrusion of the mandible caused by occlusion. In other words, a problem arises when the position of the mandible goes beyond the appropriate biological limits because of malocclusion. Furthermore, occlusal treatment must begin with determination of the physiological position of the mandible. However, it is not necessarily easy to determine a physiological mandibular position for each patient and devise a treatment plan. This is because the correct three-dimensional position must be found in order to reposititon the deviated mandible, which then must be placed in this precise position.

Furthermore, it is necessary to obtain the scientific data needed to establish this position. It is regrettable that in the past, measurement apparatuses were often not adequate to establish the appropriate mandibular position. One method for searching out the physiological position of the mandible is to determine its deviation (shown by the abnormal path of movement) by observing the path of movement of the condyle from its deviated position.

This reports presents a case where occlusal reconstruction was performed after determining the position of the mandible using the condylar path of movement obtained from a computerized axiograph.

\section{緒言}

Craniomandibular System (CMS) は顎関節を 構成する骨, 軟骨, 関節円板, 関節円板後部結合 組織, 靶帯に加え咀嚼系の筋肉群から成り立って いる. CMS の機能は, 咬合および神経筋機構と協 調し咀緭器官の主要な機能である咀嚼, 嚥下, 発 音, 呼吸などを果たすとともに，これらの動的機 能を行う際の下顎の過度な後方あるいは側方への 偏位を予防し, 下顎を前方に位置づける役割を果 している，たとえば，関節後部結合組織は豊富な 血管網に血液を供給することによって外側勒帯や 側副靶帯とともに下顎頭の後方偏位を予防 $し^{1,2)}$, 関節円板および下顎頭に結合する外側翼突 筋, 側頭筋前腹の一部の筋肉, さらに咬筋深層の 一部の筋肉などの閉口筋は, 下顎を前方に位置づ ける重要な機能を営んでいる3

上下顎の歯の嵌合もまたその咬頭斜面による下 顎の前方への誘導によって, 下顎頭の後退を予防 し, 顎関節の後方部に存在する聴覚器官や平衡感 覚器官を保護する役割を果しているものと考えら れる。それゆえに CMS と咬合との調和は両者と もに下顎を前方に位置づけるという機能によっ
て，協調を保っているということができる. 多くの顎関節の機能障害は, CMS と咬合との 不調和によって発現することが示唆されてい $3^{5,6)}$. すなわち CMS による下顎頭の前方への誘 導機能と咬合に起因する下顎の強制的な後退が, その根本的な問題であり，言いかえると不正咬合 による下顎の偏位が生体の適応範囲を越えること が問題である.それゆえに，咬合治療の第一歩は， 生理的な下顎位を設定することから始めなければ ならない. しかし, 患者ごとの生理的な下顎位を 判定し, 治療計画を立案することは, 必ずしも容 易ではない.なぜなら，偏位した下顎を整復する ためには三次元的に正常な下顎の位置を見つけ出 し，そこに下顎を的確に位置づけることが必要と なり，またそれを判断するための科学的なデー夕 が必要となるからである。残念ながら過去の計測 機器は, 適正な下顎位を設定するという目的のた めには不充分なものが多い.

生理的な下顎位を模索する方法の一つとして, 偏位した下顎位からの下顎頭の運動経路を観察す ることによって, その異常な運動経路の意味する 下顎の偏位を判定することが考えられる7).

本報告では, computerized axiograph (Cadiax system, Gamma Co., Austria）を用いて下顎頭の 
a

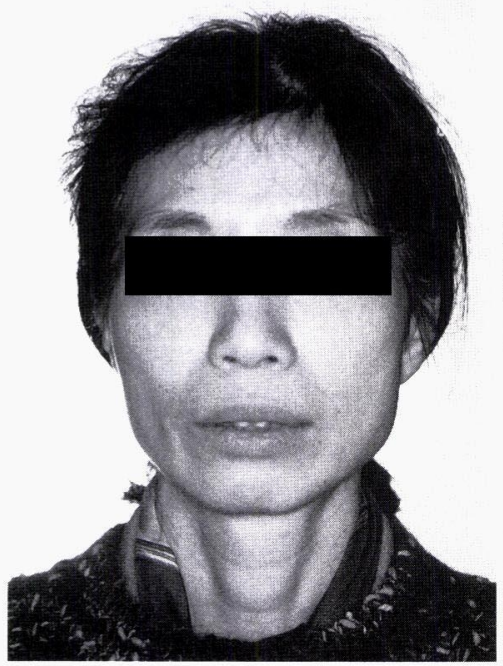

b

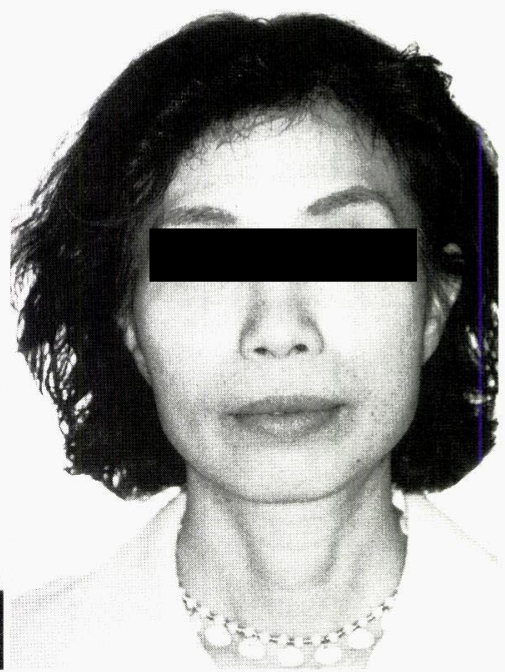

図 1 術前 ( a ) および最終補緅前 ( b ) の顔貌写真.
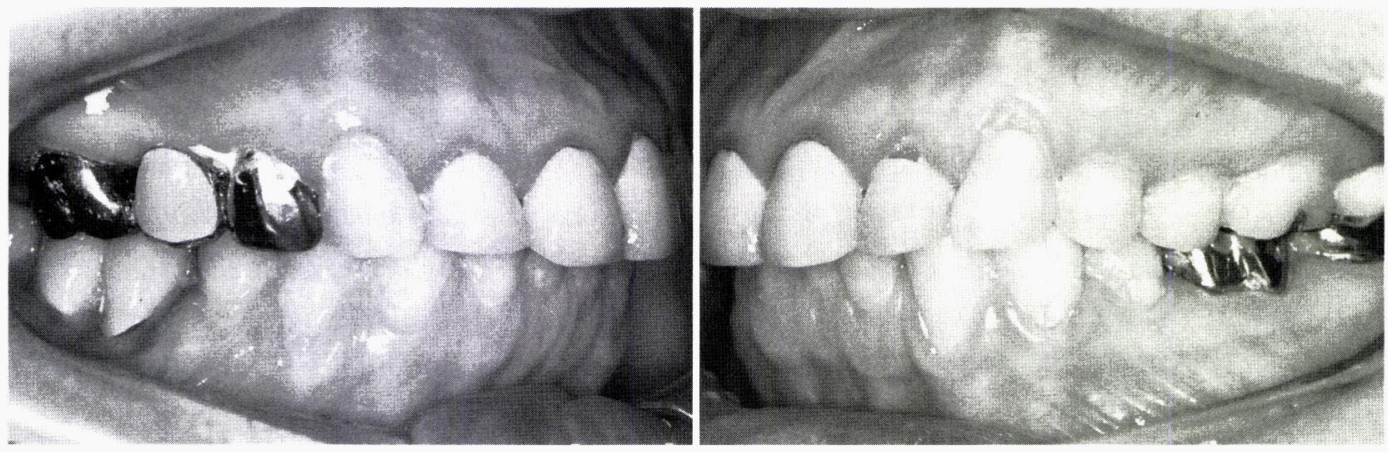

図 2 初診時の咬合状態を示す口腔写真.

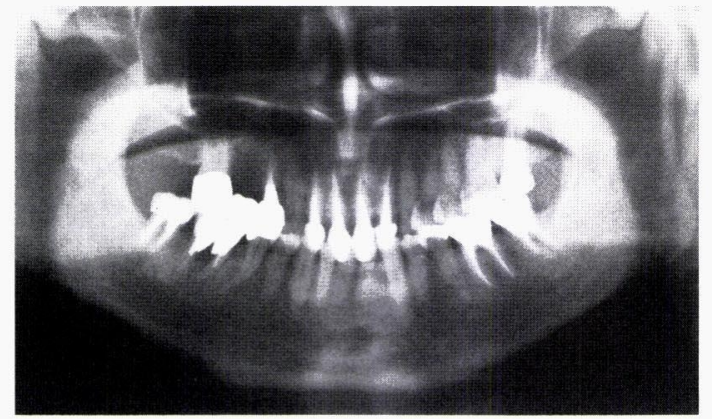

図 3 術前のパノラマX線写真.
運動経路から下顎を判断し, 咬合再構成を行った 症例について考察する.

\section{症例}

患 者：53 歳 3 力月, 女性（図 1 ）.

初 診：1994 年 1 月 29 日.

主 訴：口がうまく開けられない，澦が痛い， 首の筋肉が不快，手足がしびれ歩行がうまくでき ない, 約 2 年前より 5 件の歯科医院および大学病 院歯科を受診したが, 症状は次第に悪化し, 改善 しない（その他多くの不定愁訴が存在した）。

既往歴：患者の職業は美容師であり，立位で仕 
事をするので疲労を感じることはあるが，過去特 記すべき病歴は持っていない.

現病歴：1992 年, 最初の歯科医院で右側上顎第 2 小臼歯, 第 2 大臼歯部に架工義歯, 右側下顎第 1 大臼歯歯根を分割し，歯冠補綴を行ったが，そ のとき装着した補緅物が何となく低い感じがし た。

その後, 別の歯科医院で，左側下顎第 1 ，第 2 大臼歯および上䫇第 2 大臼歯の治療を行い, それ ぞれ金属冠を装着した.患者自身の説明によると， その頃から下顎がねじれるような感じで，時々口 が開かなくなり，また，下顎を前に出そうとして も出ないという症状が発現してきたとのことで あった。

さらに第 3 番目の歯科医院にこのことを訴え て，スプリントを作製してもらい，約 3 力月間装 着した。スプリント装着当初は一時的に症状が軽 快したものの, 次第に全身の倦怠感, 手足のしび れ，腰の痛みなどを発現し，歩行にも支障をきた

し, 美容師の仕事も困難となってしまった。

さらに別の歯科医院で，左側の金属冠の再製お よび咬合調整などを行ったが，症状は悪化するの みであった。次いで某大学病院を受診し，上顎前 歯を短くするよう削合し,筋弛緩剤を投与された. また，ノイローゼであると指摘され，内科および 精神科を受診したが, 内科的には特に異常がなく, 精神科で精神安定剤が投与された。症状は，全身 に力が入らず, 不眠を併発, 食欲もなく体重も減 少した。疼痛, 首筋の緊張, 顎関節部の疼痛など も悪化した。

咬合およびロ腔内所見：口腔内は修復処置が多 く, overjet $4.0 \mathrm{~mm}$, overbite $5.0 \mathrm{~mm}$ で, 過蓋咬 合傾向であった，上顎右側第 2 小臼歯，第 2 大臼 歯および下顎前歯 1 本が欠損しており，天然歯は 咬耗が著明であり，また露出した象牙質の陌凹が 認められ, 強度のクレンチングあるいはブラキシ ングを行っているものと推察された。さらに，そ の影響で唇側歯頸部の歯質の欠損および，歯肉の 退縮も著明であった（図 2 )。

パノラマX線写真所見：図3で判断されるよう に, 上顎では右側第 1 小臼歯， 4 前歯，左側第 2 大臼歯および，下顎の右側第 1 , 第 2 大臼歯，左
側第 1 , 第 2 大臼歯は根管処置がなされていた. 下顎右側第 1 大臼歯は近遠心根が分離されてお り，歯槽骨縁の退縮が認められた。

アキシオグラフによる下顎頭運動経路の解析： 下顎の開閉口運動に伴う下買頭運動経路を観察す ると, 開口運動に伴って, 右側下顎頭は前方 4 5 $\mathrm{mm}$ 移動時に内側に転位し, その後は最大開口位 まで，ほほ直線的に前進していた(図 4 )。閉口運 動では，最大開口位から直線的に後退し，下顎基 準位（RP）の $2 \mathrm{~mm}$ 前方より外側に偏位してい た.

一方，左側下顎頭は開口に伴って次第に外側に 偏位し，最大開口位に近づくと約 $0.5 \mathrm{~mm}$ 内側に 偏位するという経過を示したが, 閉口運動では, 直線的に後退して RP の $2 \mathrm{~mm}$ 前方より内側に偏 位した。また，矢状面トレースにおいて，RPから 前方 $2 \mathrm{~mm}$ の範囲に変曲パターンを示していた。 これらの運動経路は, 下顎の前進後退運動におい ても，基本的には同様のパターンであった。

下顎位の診査 (EMPI) では, RP と ICP との 間および RCP（最後方接触位, retruded contact position）と ICP との間に下顎頭の圧迫（compression）が認められ，咬合支持の喪失が疑われ た.また，RP と安静位 (rest position) との間で は anterior postioning（下顎頭の滑走運動経路上 で前方位をとる）が認められた。

これらの結果から，本症例の顎関節は，関節円 板の前内方転位（右側）および前外方転位（左側） を伴ったレシプロカルクリックと判断された。ま た，治療目標としての下顎位 (therapeutic reference position, TRP) は, 左右下顎頭とも約 $2 \mathrm{~mm}$ 前方で， $0.5 \mathrm{~mm}$ 左側と判断された。

診断および治療計画：本症例は，これまでの症 状の推移, 現在の咬合状態および下顎頭こ運動パ ターンの分析結果，さらに下䫟位の馀査結果を総 合すると, 歯科治療に起因した咬合位の変化によ る下顎の後右方偏位，および関節円板の転位が根 本的な問題点と考えられた。それゆえに治療目的 としては，まず偏位した下㴿を修正し，咀嚼筋群 を含む下顎頭蓋系 (CMS) の安静化を図る必要が あると考えられた。そのためには，第一段階とし てスプリントなどを利用して下顎を TRP に保持 


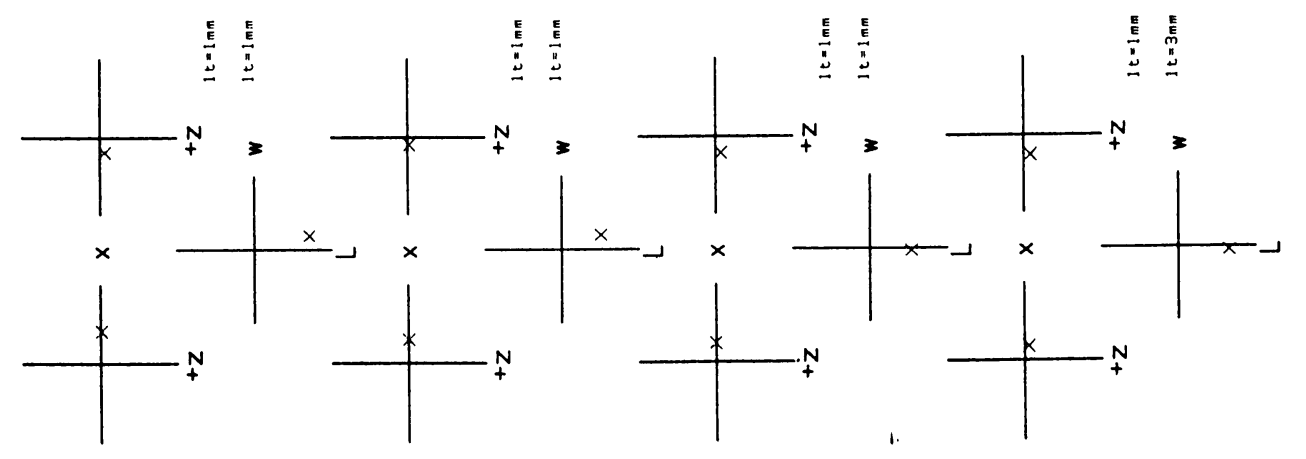

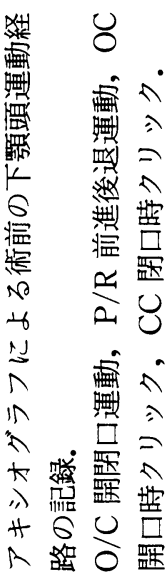

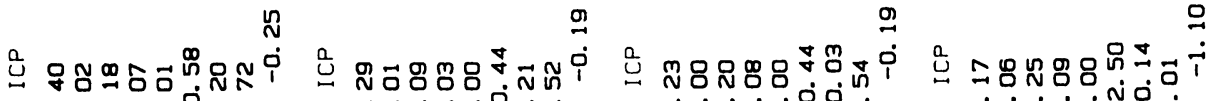

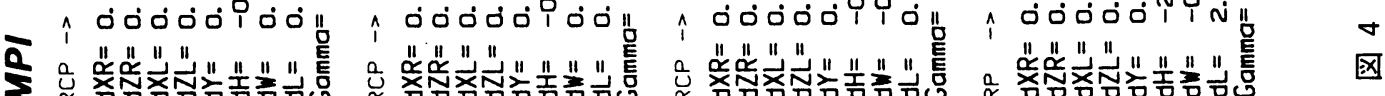

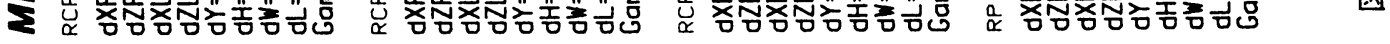
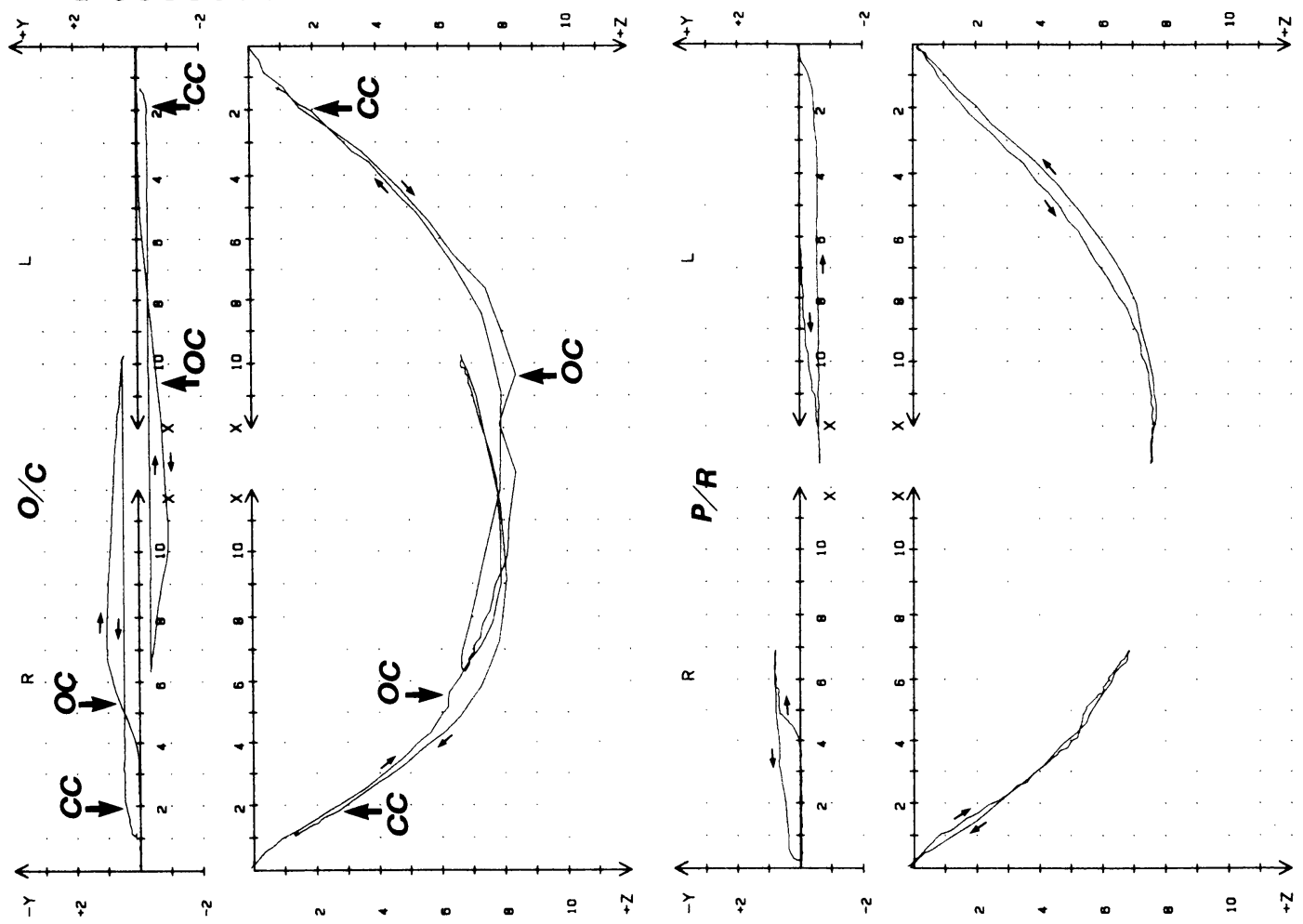

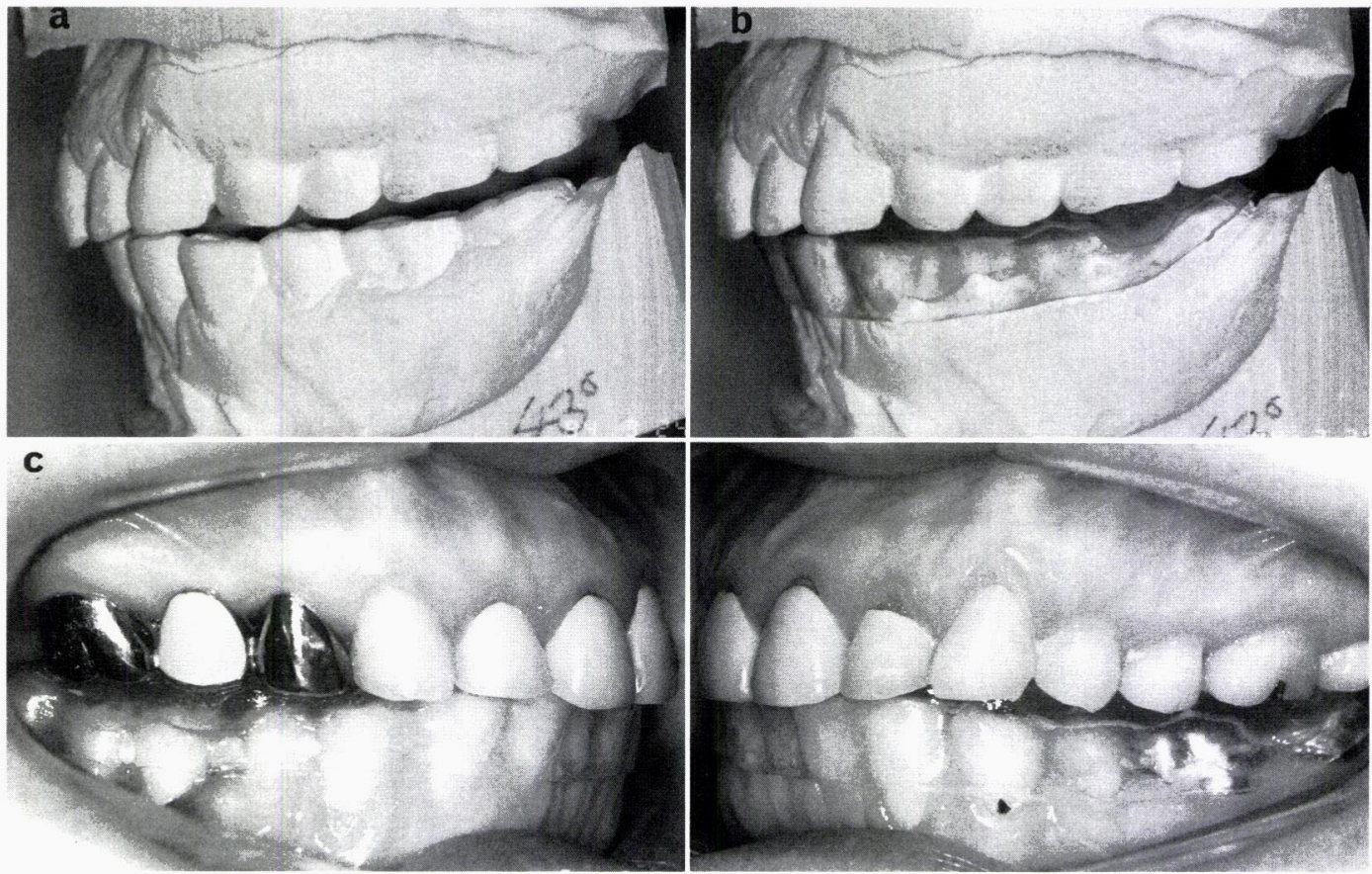

図 5 初期の治療目標としての下頡位（a）で製作したスプリント（b)，およびそれを装着した時の 口腔内写真 $(c)$
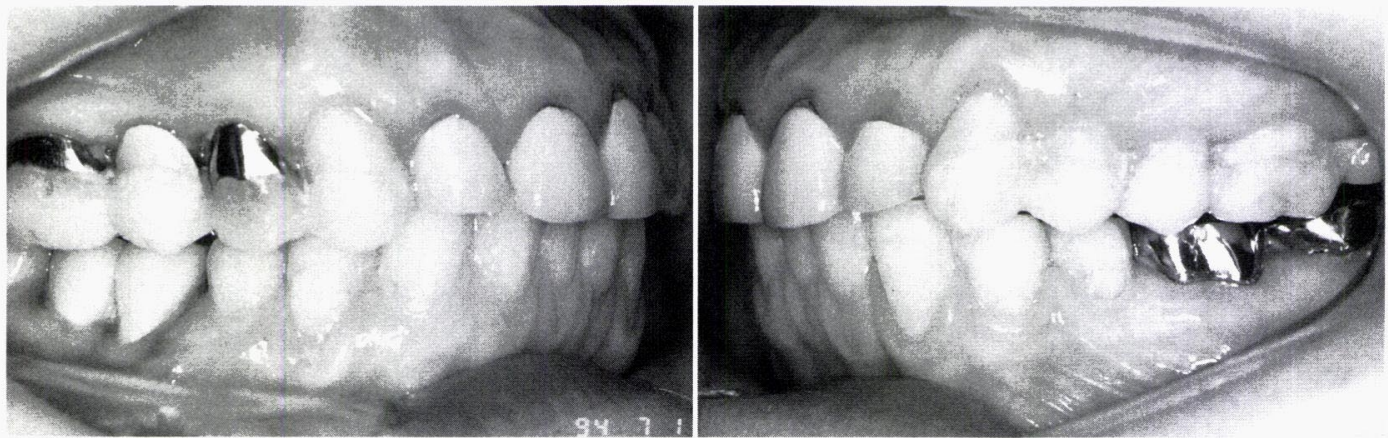

図 6 順次誘導咬合を賦与した機能的スプリント。ワックスアップ後硬質レジンにおきかえ上顎臼 歯部に接着した.この時点で下顎位は $3 \mathrm{~mm}$ 前方となっている.

することとした，その後は生理的な下澦位におい て咬合支持を獲得する必要があると思われるの で, 修復処置されている歯を中心に咬合の再構築 を行うことにした.

治療経過：まず，治療目標の下顎位に下顎を近 づけるために, SAM 咬合器上で TRP を再現し た. 下顎歯列に適合するプリントの基礎床を，イ ンプレロンを用い，バイオスターを利用して作製 し，その咬合面部に即時重合レジンを盛り上げ，
TRP で咬合させることによって，下顎のスプリ ントを作製した（図 5 ).

スプリントの咬合面はフラットな面とせず，上 顎歯の舌側咬頭が $0.5 \sim 1.0 \mathrm{~mm}$ の高さで嵌合す るように，陷凹部を残すようにした。スプリント は食事中を除いて 1 日中装着するように指示し た. 約 1 力月後, 腰痛や手足のしびれ感, 頭痛な どは消退し, 歩行もほほ支障なく行えるように なった。しかし, 精神安定剤の服用はなお継続し 
ており, 顎関節の軽度の不快感が残存していた。 そこでスプリントを再度調整し，下顎をさらに 1 $\mathrm{mm}$ 前方に位置づけるようにした。

さらに 1 力月後には，ほとんどの不定愁訴は解 消したので，スプリントによって整復した下顎位 ですべての機能運動を行えるようにするため，上 顎左右犬歯から第 1 大臼歯まで, その咬合面に ワックスアップを行い, これを硬化レジンに置き 換えることによって機能的なスプリントを作製 し，上罰歯列咬合面に接着した。この接着性スプ リントは, 本症例の左右の顆路傾斜角から計算さ れたオクルーザルガイダンスの傾斜を再現し, 側 方運動時には順次誘導 (sequential guidance) と なるように作製した（図6）。

約 2.5 力月間, この機能的スプリントを使用さ せたところ, 咀嚼機能が回復し, 食欲も増進した とのことであった. 体重も次第に増加した.アキ シオグラフによってこの時点での下顎頭の運動経 路を調べたところ, 開閉口運動時の矢状面トレー スでは比較的スムーズな経路となっていたが，な おわずかに側方的な偏位が認められた（図７）。

本症例の下顎位は, 可撤式スプリントおよび固 定式スプリントによって, 初診時の下顎位からす でに $3 \mathrm{~mm}$ 前方位に誘導していたが，EMPIによ るとこの時点での RP-ICP の差は $0.8 \sim 1.0 \mathrm{~mm}$ の範囲であった。このことは, 新しい下顎位にお ける顎関節の諸構造, あるいは CMS の適応が起 こった結果と推察された.

そこで, 最終的に補緅処置が必要な歯の歯冠形 成を行い, 最終補経のための軗間修復物を作製す ることにした. 下顎前歯を除くすべての歯に対し て全部被覆冠あるいは一部被覆冠のための歯冠形 成を行い, 印象採得後, SAM 2 咬合器にマウント した.この時の下顎位は, アキオシオグラフによ る下䫟頭運動経路上になお軽度のクリックが残存 していること, 患者自身ももう少し下顎を前方に 出した位置が楽であると訴えたこと, さらに RPICP の差が大きくないことなどを考慮し, さらに $1 \mathrm{~mm}$ 前方位とし後方誘導路 (retrusive guidance）を上額第 1 小臼歯部に設定しワックスアッ プを行った (図 8 ). 初診時からみると合計 $4 \mathrm{~mm}$ の下顎の前方移動を行ったことになるが，この暫
間修復物による下買位の誘導によって 2 力月後に はほとんどの不定愁訴は解消した（図 1，9）。

また，EMPIによる下顎位の診査では RP-ICP の差は約 $0.7 \mathrm{~mm}$ であった. 歯冠形成後の暫間修 復物による咬合再構築後, 約 3 力月を経過しても なお不定愁訴などの再発は認められないので, 最 終補綴治療を行った（図 10).

\section{考 察}

いわゆる顎関節内障の概念が Farrar (1978, 1979) ${ }^{8,9)}$ によって提出されて以来, 下靧位の考え 方は大きく変化してきた。すなわち, 䪽関節内障 における関節円板の転位は, 単に関節円板の偏位 を意味するものではなく, 下顎の偏位を示す重要 な指標であり ${ }^{5,10)}$, それゆえに関節円板転位の様式 や，偏位した下顎位からの下顎頭の運動経路は, 適正な下顎位を模索する上で貴重な情報を提供す るものとなっている。

下顎の偏位の多くは, 咬合支持の变失や咬頭干 涉によって誘発されたものであることを考える と, 咬合再構成における適正な下顎位の設定と, その位置での咬合構築は stomatognathic system の機能回復にとって最も基本的で重要なステップ である，滑膜関節である顎関節がその機能を遂行 する上で下顎頭の運動経路は, 元来きわめてス ムーズな乱れのない軌跡を示すことが知られてい る。しかし，下顎位が偏位した場合，下顎頭と関 節円板, 勒帯などとの解剖学的関係の変化やこれ らの構造物の器質的変化に応じ, 当然, 運動経路 のパターンも変化してくることが報告されてい る ${ }^{11,12)}$. Cadiax system は, このような運動経路 の変化を調べる上で, 最もすぐれたシステムのひ とつと考えられる.

本症例では，その運動経路から右側下罘頭は 2 $\sim 3 \mathrm{~mm}$ 後方で $0.8 \mathrm{~mm}$ 外方に, また左側下顎頭 は後方に約 $3 \mathrm{~mm}$, 内側に $0.5 \mathrm{~mm}$ 偏位したもの と判断された。それゆえに, 治療過程においては まずスプリントによって偏位した下顎位を整復 し, 治療途上における下頷頭の運動経路の再診査 によって,さらに $1 \mathrm{~mm}$ の下顎位の前方への設定 が示唆されたことから暫間修復製作時にこの量を 


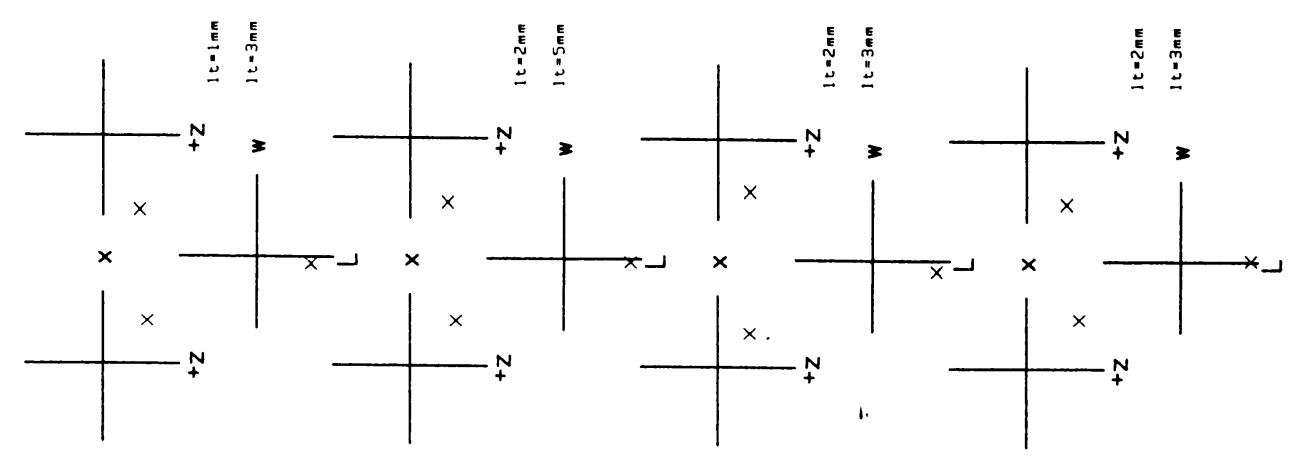

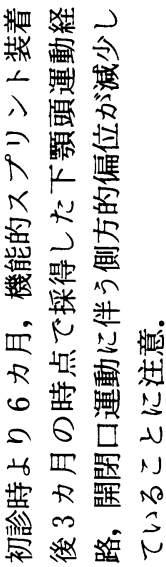

こ

$2 \quad \frac{1}{2}$ ₹

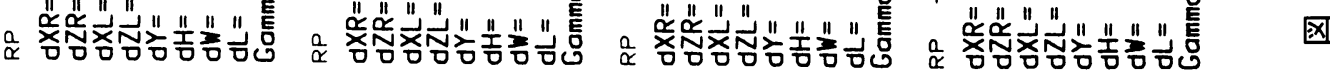
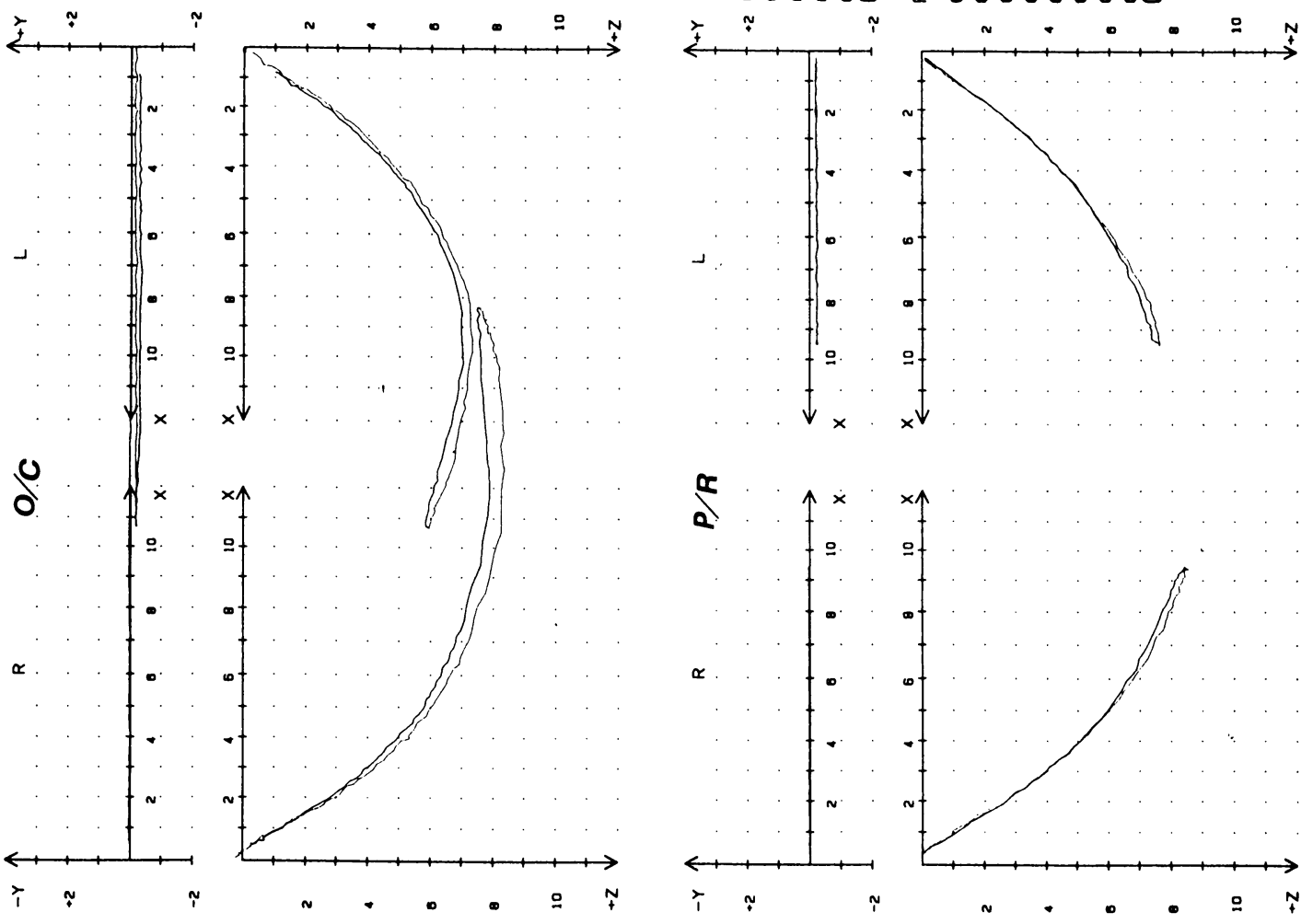


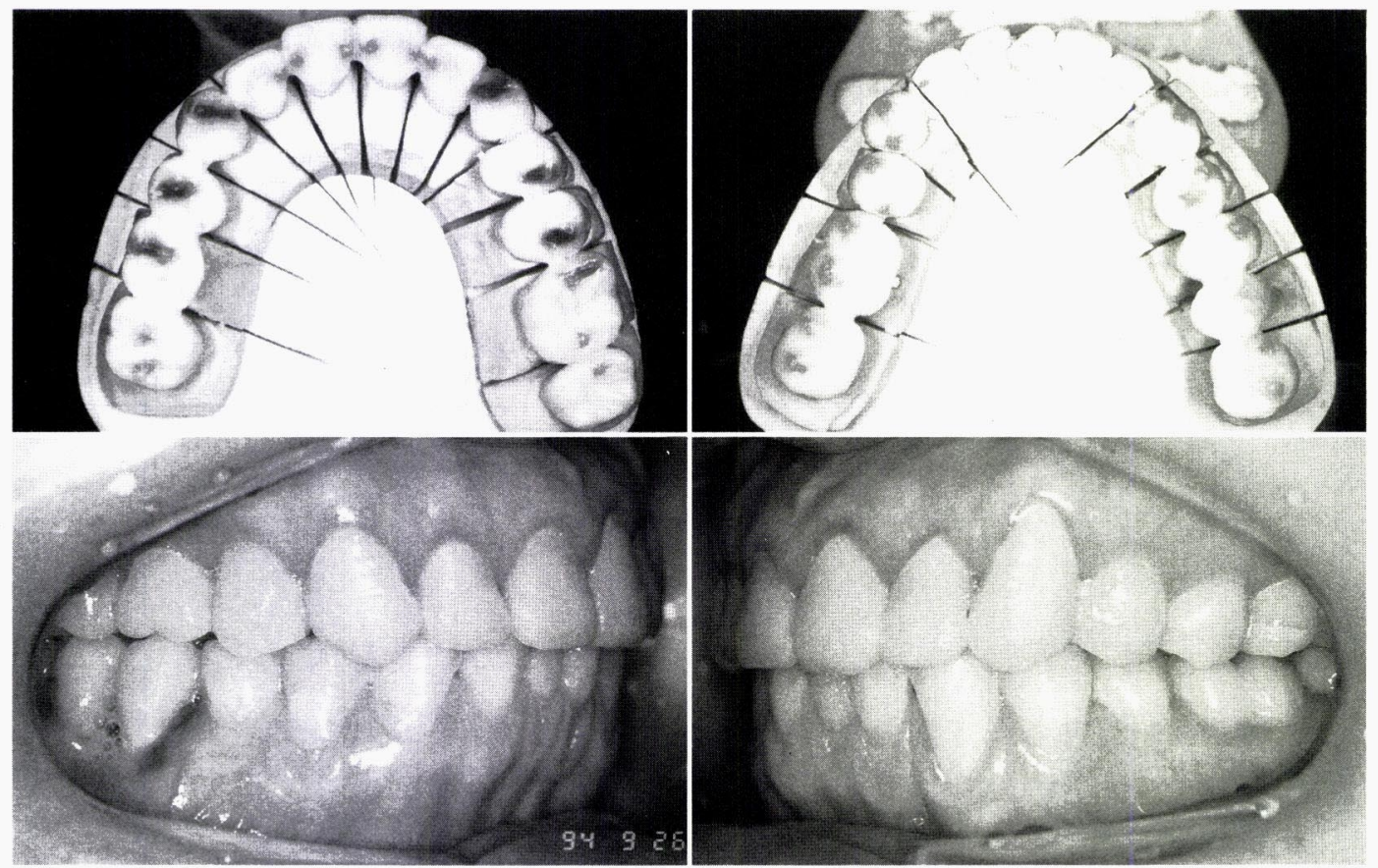

図 8 暫間補綴物製作のためのワックスアップ. 咬合様式は順次誘導咬合, 下䫟位は初診時から見 ると約 $4 \mathrm{~mm}$ 前方位となっている(但し，この時点では下顎を後方に誘導しても $1 \sim 1.5 \mathrm{~mm}$ 程度後退するのみであった).下顎の後方運動に対しては後方誘導路が賦与されている（上 段). 装着後の口腔内写真 (下段).
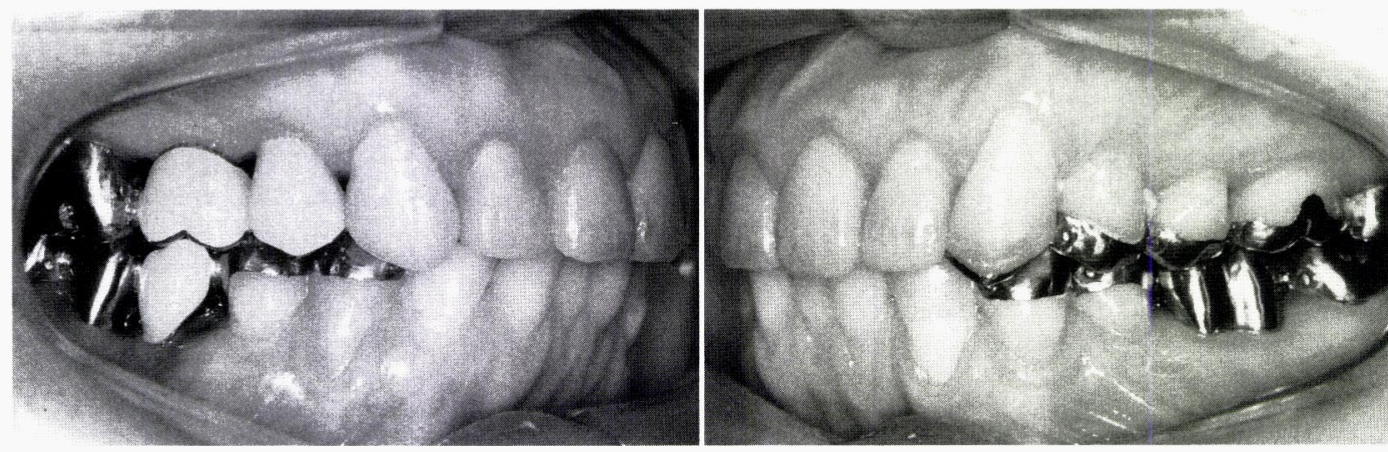

図 9 最終補綴物装着後の口腔内写真.

整復した，すなわち，治療前後で下顎位は前後的 に約 $4 \mathrm{~mm}$ 前方に位置づけたことになる。

このような下㖽位の位置づけを行う場合には, 単に下顎を前方に位置づけるのみでなく，その下 顎位を保持するための咬頭嵌合やすべての㐘の適

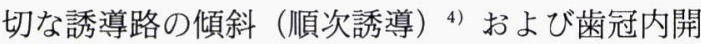
口角を与えるとともに下顎が後方に運動した場 合，後方歯の干渉を除くための誘導路（後方誘導
路）を与えなければならない.これらの誘導路を 与えることによって，初めて下顎頭を適切に位置 づけることが可能となる.

最近, Schellhas ${ }^{13,14)}$ や Chuong ${ }^{15)}$ らによって 下顎頭に加わる圧迫や関節円板の転位による下顎 頭への血液供給の不足や炎症による筋線維の線維 化によって，下顎頭の重篤な退行変性や懐死を誘 発することが報告されている，下顎頭への圧迫や 


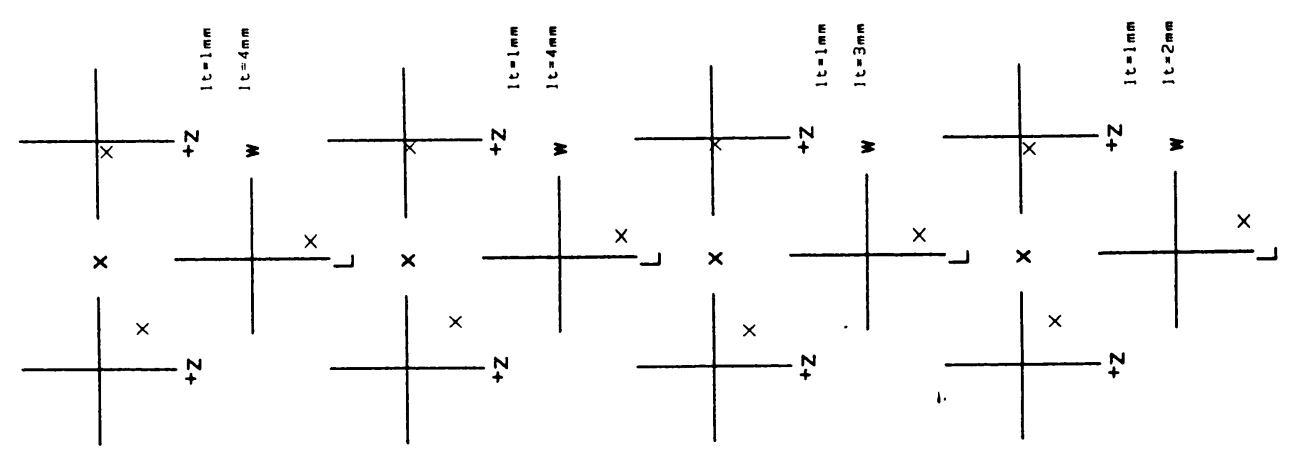

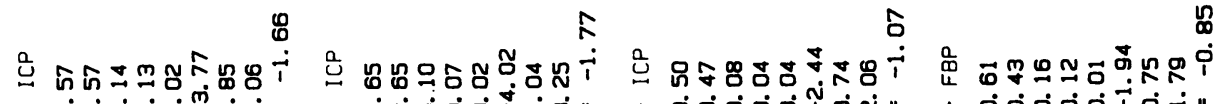

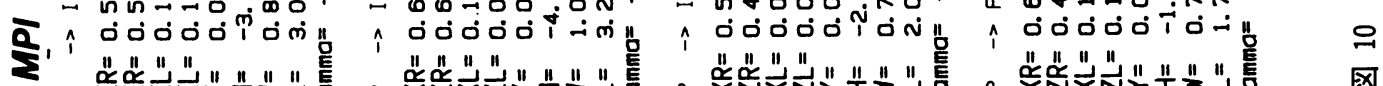

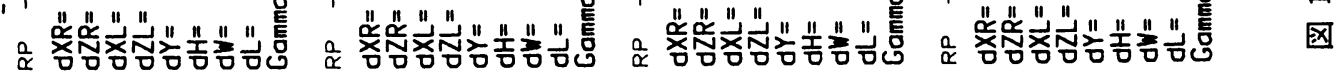

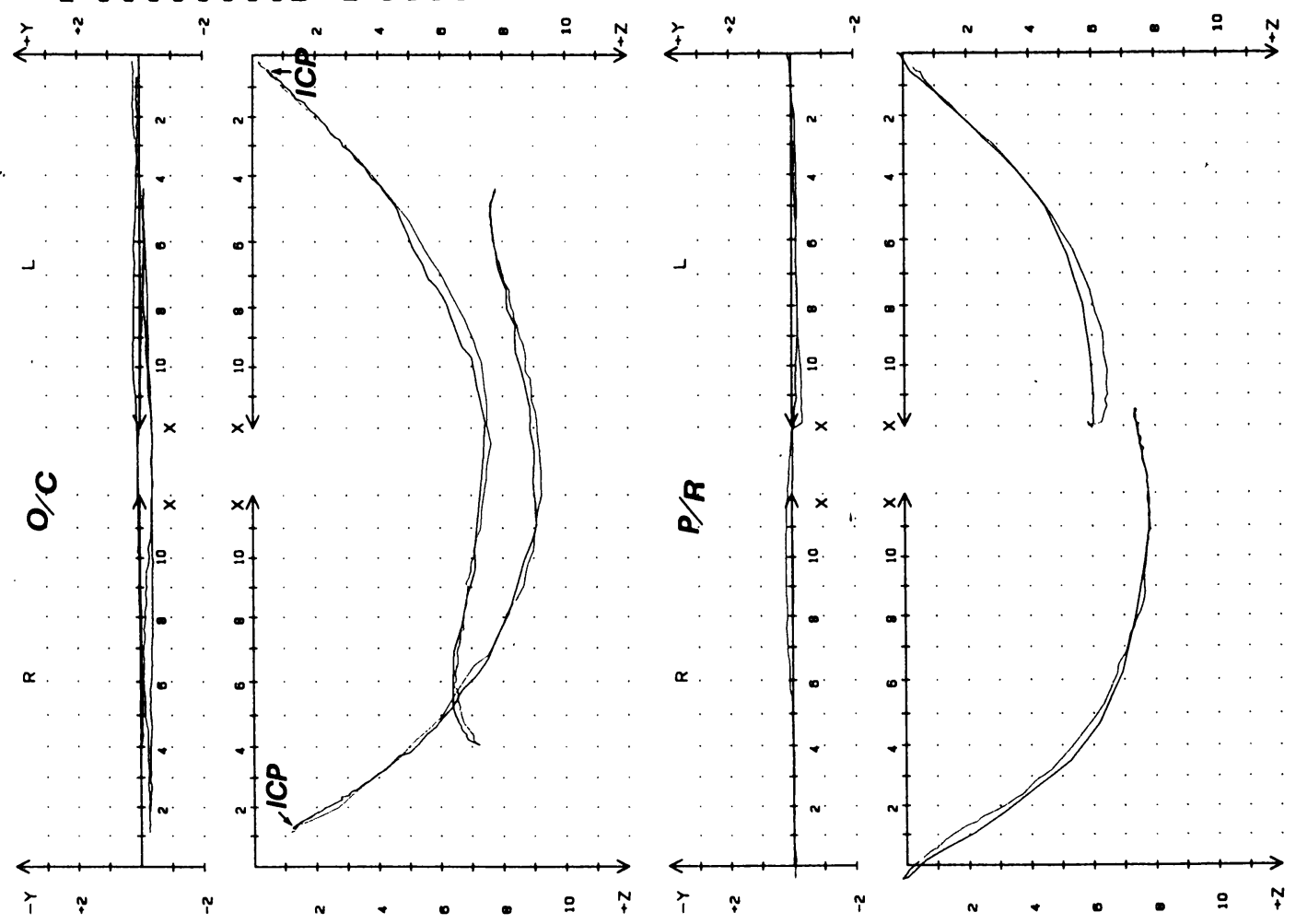


関節円板の転位を改善あるいは予防する上で，下 顎位の整復を含む咬合治療はきわめて重大な役割 を担っていることを考えると, 下顎位診断の重要 性とその日常臨床における咬合再構成への応用の 必要性を再認識する必要があろう。

\section{結論}

顎関節の機能障害および全身の不快感, 不定愁 訴を訴えた 53 歳（女性）の患者に対し Computer axiograph (Cadiax) を用い, その運動経路の解 析から下顎の偏位を診断し，スプリントと暫間修 復によって整復した下頡位において咬合再構成を 試みた。

前方に約 $4 \mathrm{~mm}$, 左方に $1 \mathrm{~mm}$ 修正した下顎位 では, 比較的スムーズな下䪽頭の運動経路を示す ように変化し，またほとんどの枵関節症状および 全身症状が消失したことから，咬合治療において 下顎位の整復がきわめて重要であることが示唆さ れた。さらに, 整復した下顎位における咬合再構 成において適正な歯の誘導路，とくに後方誘導路 を与える必要性が確認された。

\section{参考文献}

1) Hall, M. B., brown, R. W. and Baughman, R. A. : Histologic appearance of the bilaminar zone in internal derangement of the temporomandibular joint. Oral Surg Oral Med Oral Pathol $58: 375-381,1984$.

2) Isacsson, G. and A. M. : Tissue identification of the TMJ disk attachments and related vascularization. J. Craniomand. Pract. 3 : 374379, 1985.

3) Zenker, W. : Das retroarticuläre plastische Polster des Kiefer-gelenkes und seine mechanische Bedeutung. ZAnat Entwickl-Gesch 119:375-388, 1956.

4) Reusch, D., Lenze, P-G. Fisher, H. and Kulmer, S. : Rekonstruktion. Von Kauflächen und Frontzähen Druckrei Hachenburg $\mathrm{GmbH}, 1990$.

5）佐藤貞雄, 秋本 進, 不島健持, 石井 穣：顎
関節を考慮した不正咬合治療．東京臨床出版， 1995.

6) Owen, A. H. III : Orthodontic/Orthopedic treatment of craniomandibular pain dysfunction Part 2; Posterior condylar displacement. J. Craniomand. Pract. 2 : 334-349, 1984.

7) Piehslinger, E., Celar, A., Celar, R., Slavicek, R. : Computerized axiography: principles and method. J. Craniomandib. Pract. $9: 344-$ 355, 1991.

8) Farrar, W. B. : Characteristics of condylar patt in internal derangements of the TMJ. J. Prosth. Dent. 39 : 319-323, 1978.

9) Farrar, W. B. and Mccarty, W. L. : Inferior joint space arthrography and characteristics of condylar paths in internal derangements of the TMJ. J. Prosth. Dent. 41: 458-555, 1979.

10) Fushima, K., Sato, S., Suzuki, Y. and Kashima, I. : Horizontal condylar path in patients with disk displacement with reduction J. Craniomand. Pract. 12:78, 1994.

11) Slavicek, R. : Clinical and instrumental functional analysis for diagnosis and treatment planning Part 1-Part 2. J. Clin. Orthod. 22 : JEN-DEC.

12) Sato, S. and Suzuki, Y. : Application of SAM system to the orthodontic diagnosis for malocclusion with temporomandibular joint dysfunction, Bull. of Kanagawa Dent. Col. 19:151-161, 1992.

13) Schellhas, K. P., Wilkes, C. H., Fritts, H. M. Omlie, M. R. and Lagrotteria, L. B.: Mr of osteochondritis dissecans and avascular necrosis of the mandibular vonfyle. AJNR 10 : $3-12,1989$.

14) Schellhas, K. P., Piper, M. A. and Omlie, M. R.: Facial skeletal remodeling due to temporomandibular joint degeneration: an imaging study of 100 patients. AJNR $11: 373-$ 383, 1990.

15) Chuong, R. and Piper, M. A. : Avascular necrosis of the mandibular condyle-pathogenesis and of management, OS OM OP $75: 428-432,1993$.

別刷請求先: 佐藤貞雄 